\section{Space programme: accentuating the cooperative}

The Soviet Union will celebrate the twentieth anniversary of Sputnik-1 next year at the same time as the diamond jubilee of the October Revolution. Vera Rich reports

THE launching of Sputnik-1 on October 4,1957 , inaugurated a whole series of Soviet "firsts" in space, frequently coordinated (so far as the state of the art permitted) with some notable anniversary. The centenary of Lenin's birth was marked in 1971, for example, by the launch of the first orbiting spacestation, Salyut 1; and it is entirely possible that the Soviet space programme is planning some equally prestigious "spectacular" for the sixtieth anniversary of the Revolution. The current emphasis, however, suggests that the year will be marked first and foremost by an extension of "fraternal cooperation" in space between the Soviet Union and her Comecon partners.

This trend is not a cover-up for the recent set-back to the Soviet space programme provided by the aborted Soyuz 23 mission when it failed to link up with the Salyut 5 station. On the contrary, it is perhaps best exemplified by the joint communique issued by Soviet Academician Boris Petrov and GDR Academician Karl Gröte, after the previous highly successful Soyuz flight. Soyuz 22 had carried a "multispectrum" camera from the Karl Zeiss (Jena) works, and was heralded as a new phase in Comecon cooperation in space. The same theme was enthusiastically repeated by the Soviet and Comecon media.

The presence of foreign equipment aboard a Soviet spacecraft is not new; French instruments were carried on Lunokhod 2 and by the Mars 5, 6, and 7 probes. Comecon has had its own space programme, Interkosmos, since 1967, and has launched 16 orbital satellites and 4 high altitude rockets. The Soviet Union supplies the rocketry for all Interkosmos launches, while her Comecon partners supply certain instruments, so the use of such instruments in a formally Soviet mission might seem a fairly predictable development. Why, then, was it greeted with such acclaim?

Propaganda plays a certain part: the current Comecon five-year plan, while temporarily soft-pedalling the final goal of total economic integration, is concentrating on a short term drive
(15-20 years) towards integration in certain significant areas, notably sophisticated instrumentation. The PetrovGröte communication clearly refers to this policy, stating that East German participation in Soyuz 22 was "part of the process of Socialist integration in one of the newest regions of contemporary science and technology".

The concept of an integrated science policy is, however, meeting with opposition from certain research bodies and institutions in the member countries of Comecon, particularly where, as in Poland, there is a long native scientific tradition. Such bodies have been openly accused of "autarchic" (that is, nationalist) tendencies, necessitating the intervention of Party and
Government. Emphasis on cooperation in such a prestigious field as space research might well be interpreted as simply a tactical measure to offset in the mind of the public the effect of this academic discontent.

Earlier this year it was announced that Interkosmos would start a manned space programme with multinational crews. The first launches are scheduled for 1977 and the cosmonauts are already in training. It would seem, however, that each crew is to include at least one Soviet cosmonaut. Since the Soyuz 11 tragedy, though, the Soyuz missions have used a two-man crew, instead of the previous three-a change apparently associated with the decision that the crew should wear space-suits during re-entry as a safety measure. If the current pattern continues, it will take at least eight flights for each country to get one representative in space.

\title{
Expeditions: resources rationally used?
}

The rational use of natural resources in the Soviet economy is a major target of the current five-year plan. It is also a dogma which can be invoked to justify most things. That includes geological and geographical expeditions, where the data obtained can be interpreted to relate to the needs of prospecting, oceanography, climatology and other fields of practical significance. In the case of the expeditions of summer 1976, the range is from the immediately practical to the extremely remote in terms of the economy's needs.

On the one hand, there was massive Soviet participation in the 200strong joint Comecon expedition to Mongolia, which worked within a surveying programme aimed at ensuring 10-20 years' supply of fuel and material resources for the Comecon bloc. During this first field season some $7,000 \mathrm{~km}^{2}$ was systematically surveyed, and several outcrops of "valuable raw materials" (so far unspecified) were located. The expedition is a long-term project; to facilitate its work in future seasons a special base is to be established next year on the outskirts of Ulan-Bator, the Mongolian capital, with administrative and living accommodation as well as such services as shops and a kindergarten.

Although even the most cautious planners could hardly doubt the practical value of the Mongolian expedi- tion, they might feel a little different about the other major long-term project inaugurated this summer. This is the scheme to sink a $16-\mathrm{km}$ borehole at Saatly in the Murganskaya steppe. This area is a "geological anomaly", where the crust is significantly thinner. In 1970 , a pilot borehole was sunk to a depth of $6,240 \mathrm{~m}$. If successful the new project will allow material to be recovered from the upper mantle. The theoretical value of such specimens would be immense; the most practical outcome of the expedition may well be the experience which the Soviet oil industry will gain in sophisticated drilling techniques.

One of the most practicallyorientated expeditions this summer was that of the Siberian Energy Institute of the Soviet Academy of Sciences, which set out to survey possible power resources in the construction area of the new Baikal-Amur Mainline railway. The Baikal area has long been famous for its geographical and ecological riddles; this expedition discovered another, a complex of "classical mountain glaciers" at a relatively low altitude and unexpectedly far south. The plans for the railway have from the beginning incorporated a number of conservation measures aimed at preserving the unique Baikal habitat. The presence of these glaciers "in direct proximity of the line" is causing the relevant experts considerable concern. 